\title{
ON THE NOTIFICATION OF DOUBTFUL CASES AND THE HOSPITAL ISOLATION OF SCARLET FEVER AND DIPHTHERIA.
}

\author{
By ARTHUR NEWSHOLME, M.D.*
}

Notification of Doubtful Cases.-Scarlet fever caused only one death during 1901. This indicates the extreme mildness of the present type of this disease. This has caused failure to recognise it in a considerable number of instances. The meshes of the Infectious Disease (Notification) Act are, in fact, too large to catch all the cases of the present type of scarlet fever, and, as I have pointed ont elsewhere, the time is ripe for asking the Legislature for notification of suspected as well as fully recognised cases of this disease and of diphtheria. In November and December last a number of cases of searlet fever, associated with cases in which the only manifestation of scarlet fever was the occurrence of sore throat, came under observation. These were caused by an infected milk supply. ${ }^{\dagger}$ Until such anomalous suspicious attacks of illness as well as definite cases of scarlet fever are notified, we cannot hope to obtain the full measure of the possible utility of our isolation hospital. At present we may be isolating one patient while an unnotified atypical case is continuing to spread infection. This fact is no argument against hospital isolation, but indicates the desirability of power to enforce some measure of isolation for suspected cases. The notification of such suspected cases would enable us to link case with case by a chain of evidence as to infection, and thus much more effectually prevent its transmission. At present we are frequently baffled by absence of information as to these intermediate attacks of anomalous character.

Tests of Utility of Isolation Hospital.-The utility of our isolation hospital in preventing the spread of scarlet fever may, to some extent, be gauged by the number of secondary and subsequent cases occurring in the same household after removal. During 1901, out of households from which cases of scarlet fever were removed to hospital, two cases occurred in fourteen houses, three cases in tive houses, and four cases in one house. Three other cases occurred in a large institution for poor girls, and two cases were brought to a cottage in Brighton from a school outside the borough.

\footnotetext{
* From Annual Report, 1902.

+ A full account of these cases is given in the Journal of Hygiene for April, 1902.
} 
The relationship between the first and the subsidiary eases is shown in Tables A and B.

Table A.

Subsidiary Cases of Scarlet Fever in Households from which the First Patient was removed to Hospital before the Onset of the Second Patient's Attack.

Number of Days elapsing between Onset of First Case and of Second Case.

$\begin{array}{cc}\text { Days. } & \text { Cases. } \\ 3 & 3 \\ 4 & 1 \\ 5 & 1 \\ 6 & 2 \\ 9 & 1 \\ 17 & 1 \\ 18 & 1\end{array}$

Number of Days elapsing between Removal of First Case and Onset of Second Case.

$\begin{array}{cc}\text { Days. } & \text { Cases. } \\ 1 & 1 \\ 2 & 3 \\ 3 & 1 \\ 4 & 1 \\ 5 & 1 \\ 7 & 1 \\ 15 & 1 \\ 17 & 1\end{array}$

Table B.

\section{Subsidiary Cases of Scarlet Fever in Households from which the First Patient was only removed to Hospital at the same time as or later than the Second Patient.}

Number of Days elapsing between Onset of First and Second Cases.

$\begin{array}{llllc}\text { Days. } & & & & \text { Cases. } \\ \text { Same day } & \ldots & \ldots & \ldots & 3 \\ 1 \text { day } & \ldots & \ldots & \ldots & 2 \\ \text { 2 days } & \ldots & \ldots & \ldots & 1 \\ 5 \quad " & \ldots & \ldots & \ldots & 1 \\ 10 \text {," } & \ldots & \ldots & \ldots & 1 \\ \text { Doubtful } & \ldots & \ldots & \ldots & 1\end{array}$

In addition to the above, twenty-eight patients were treated at home. Among these one secondary case occurred. The two imported cases previously referred to, which were treated in an isolation cottage, are not included in the above results.

In regard to sixty-eight hospital-treated cases and fifteen hometreated cases, the necessary particulars for inclusion in the following table, which summarizes our results for three conseeutive years, were obtainable :

$$
\text { Table C (1899 to } 1901 \text { inclusive). }
$$

\section{Cases Removed to Hospital.}

\begin{tabular}{|c|c|c|c|c|c|}
\hline $\begin{array}{l}\text { Nun } \\
\text { of }\end{array}$ & & $\begin{array}{l}\text { Numbe } \\
\text { in the s } \\
\text { who esc } \\
\text { Scar? }\end{array}$ & $\begin{array}{l}\text { Persons } \\
\text { Family } \\
\text { having } \\
\text { ver. }\end{array}$ & $\begin{array}{l}\text { Number } \\
\text { in Second } \\
\text { Families in } \\
\text { Honse wh } \\
\text { having Sca }\end{array}$ & $\begin{array}{l}\text { Persons } \\
\text { and Third } \\
\text { the same } \\
\text { lo escaped } \\
\text { rlet Fever. }\end{array}$ \\
\hline $\begin{array}{l}\text { nder } 22 \\
832\end{array}$ & $\begin{array}{c}\text { Over } 20 \\
72\end{array}$ & $\begin{array}{c}\text { Under } 20 . \\
1,705\end{array}$ & $\begin{array}{c}\text { Over } 20 \\
1,676\end{array}$ & $\begin{array}{c}\text { Under } 20 . \\
354\end{array}$ & $\begin{array}{c}\text { Over } 20 \\
774\end{array}$ \\
\hline
\end{tabular}




\section{Cases Treated at Home.}

\begin{tabular}{|c|c|c|c|c|}
\hline Numb & & $\begin{array}{l}\text { Nunber of } \\
\text { in the same } \\
\text { who escaper } \\
\text { Scarlet } F\end{array}$ & $\begin{array}{l}\text { Persons } \\
\text { Family } \\
\text { having } \\
\text { ever. }\end{array}$ & $\begin{array}{l}\text { Number of Persons } \\
\text { in Second and Third } \\
\text { Fanilies in the samed } \\
\text { House who escaped } \\
\text { loving Scarlet Fever. }\end{array}$ \\
\hline $\begin{array}{c}\text { Under } 20 \\
132\end{array}$ & $\begin{array}{c}\text { Over } 20 . \\
14\end{array}$ & $\begin{array}{l}\text { Under } 20 . \\
181\end{array}$ & $\begin{array}{l}\text { Over } 20 . \\
253\end{array}$ & $\begin{array}{cc}\text { Under } 20 . & \text { Over } 20 \\
22 & 56\end{array}$ \\
\hline
\end{tabular}

Number Attacked per 100 Persons not previously having had Scarlet Fever.

\section{Cases Removed to Hospital.}

\begin{tabular}{|c|c|c|c|}
\hline \multicolumn{2}{|c|}{$\begin{array}{c}\text { Attack-rate among those } \\
\text { living in the same Family } \\
\text { and Aged }\end{array}$} & \multicolumn{2}{|c|}{$\begin{array}{l}\text { Attack-rate among Total } \\
\text { Persons living in the same } \\
\text { House and Aged }\end{array}$} \\
\hline $\begin{array}{c}\text { Under } 20 . \\
32 \cdot 7\end{array}$ & $\begin{array}{c}\text { Over } 20 \\
4 \cdot 1\end{array}$ & $\begin{array}{c}\text { Under } 20 \text {. } \\
28 \cdot 8\end{array}$ & $\begin{array}{c}\text { Over } 20 \text {. } \\
2 \cdot 8\end{array}$ \\
\hline \multicolumn{4}{|c|}{ II. Cases Treated at Home. } \\
\hline \multicolumn{2}{|c|}{$\begin{array}{l}\text { Attack-rate among those } \\
\text { living in the same Family } \\
\text { and Aged }\end{array}$} & \multicolumn{2}{|c|}{$\begin{array}{l}\text { Attack-rate among Total } \\
\text { Persons living in the same } \\
\text { House and Aged }\end{array}$} \\
\hline $\begin{array}{c}\text { Under } 20 \\
50 \cdot 2\end{array}$ & $\begin{array}{c}\text { Over } 20 \\
5 \cdot 2\end{array}$ & $\begin{array}{c}\text { Under } 20 \\
46.3\end{array}$ & $\begin{array}{c}\text { Over } 20 . \\
4 \cdot 3\end{array}$ \\
\hline
\end{tabular}

This table is not presented as setting forth the relative utility of home and hospital treatment; it can only show a fragment of the truth under this head. So far as it goes it is satisfactory. It shows that the attack-rate when the scarlatinal patients were removed to hospital was 32.7 per cent. among those in the same family under twenty years of age, and $50^{\circ} 2$ per cent. when the patient was treated at home. But in interpreting the table the following facts must be borne in mind :

(a) Among the hospital-treated cases a considerable number were not removed until second or even a larger number of cases in the same house had become infected. (See Tables A and B.)

(b) The hospital-treated cases were, as a rule, much less favourably situated than the home-treated cases for the prevention of the spread of infection in the incipient stages of the disease, being generally of a lower social position. This point is necessarily implied in the fact that removal to an isolation hospital was considered requisite.

(c) As there is no local prejudice against the isolation hospital, there is a process of selection in regard to home-treated cases, only those remaining at home in which the means of isolation were excellent, and in which there was no reason to suggest hospital isolation. When due weight is given to these considerations, the superiority of hospital over home isolation becomes more evident. 
The utility of hospital isolation is greatest in the cases in which prompt recognition of the disease and removal to hospital was secured. The following table shows, respecting the first case in every house in which scarlet fever occurred during 1901, the day of disease on which patients were removed:

Day of Disease on which tho Patient was removed.
No, of Primary Cases of Scarlet Ferer in each Household.
(a) Households in which only One Case oecurred.
(b) Households in which more than One Case oceurred.

Infant Montality.-Dr. Frederick Hunton, medical officer of health, Sedgefield, writes, in his annual report with reference to infant life insurance, that this is an evil which undoubtedly contributes some share in the production of this high death-rate no careful and unbiassed observer will deny. But since the welfare of an infant is so easily prejudiced by overt acts of omission rather than those of active commission, the difficulties of the onus of actual proof of crime are practically insuperable; but I feel confident, if the present system. was entirely abolished, infant life would gain in security, and no hardship would be incurred, for the decent burial of an infant is of so inexpensive a nature that none but those with ulterior objects could feel the want of it. Dr. F. H. Morison, medical officer of health, West Hartlepool, considers the only remedy to reduce the infant death-rate is education, and this can be arrived at by a scheme such as is carried on in Chesterfield, where they have an "Infant Life Protection Society," or as in Birmingham, where they have female health visitors whose duty it is to visit poor people in their homes, and instruct them in the proper manage. ment and feeding of infants. 